\title{
Hope SPRINGs eternal: A RefLection ON the PROFESSOR
}

\section{LA ESPERANZA ES ETERNA: UNA REFLEXIÓN SOBRE EL PROFESOR}

\author{
Elliot Shaw \\ Palm Beach Atlantic University \\ shaw.elliot@gmail.com
}

The summer before starting graduate school, I received a call from the dean of the philosophy department who surprised me with the opportunity of being a Graduate Teaching Assistant in his program. The field of philosophy was not my area per se, but I was thrilled to accept his offer since it was a firm area of interest and what I thought was a great chance to be immersed in a department other than my own, comparative literature. And perhaps more importantly, I was not prepared to reject the position's boon of a generous tuition waiver and monthly stipend.

A few weeks later, I was sitting in a bustling lecture hall with some two hundred undergraduates milling about the room to find seats and chat with fellow comrades, the kind of hopeful anticipation that exists only at the beginning of a semester filling the air. The hour struck for class to begin and Lester ambled into the room, a fat stack of syllabi clasped underarm. As it was the first time I had ever taught as a teacher's assistant, I was feeling slightly nervous, but that began to dissipate when Lester launched into first-day-of-class introductions. I found that despite the surliness of his appearance, which his considerable size and gruff beard did well to emphasize, he engaged the students in a friendly way, making jokes and generally treating them in a disarming, informal manner. I learned soon, too, that Lester's informality belied the masterful command he had of his tradition and discipline. 
When I was formulating plans for the coming summer the next January, it occurred to me that Lester, as the school's William F. Dietrich Eminent Scholar, might have need for a research assistant. One afternoon after class, I tried my luck and asked him if he was in need of one. His response was that he already had a fulltime assistant and could not take another, so I thanked him anyway and began considering other plans, generally considering the matter closed. I was surprised, then, when he pulled me aside after class a few weeks later to explain that the assistant he'd had for nearly a decade had accepted another position and was soon leaving. He was willing to take me on for a "trial period" (being careful to emphasize its contingency on my performance). If I proved myself capable of the job, he would hire me officially. I, of course, agreed to his conditions.

Soon thereafter I was brought in to Lester's office for training. When I walked into it, I was struck at the sight of it. A line of hardwood bookcases filled with hundreds of books greeted one upon initial entrance. On top of these were mailing bins and file boxes stacked to the ceiling. One was forced to circumnavigate the makeshift hallway these were arranged into before the room's sizable spread was unveiled. The main area, easily the size of two large offices, was comprised of two desks affixed to opposite walls with a large a large table between, a faded, pink dormitory-style couch sitting beneath the wall of windows on the room's far end, and, of course, more stacks of boxes. These various surfaces were covered with a hackneyed panorama of objects: reams of papers, large manuscripts with scribbling and sticky notes hanging out like an array of colorful tongues, old books, new books, hard drives, staplers, figurines, and so on. There was also a pantheon of framed pictures hanging above Lester's desk. It was a group of philosophers I did not know well at the time, but philosophers with whom I would become intimately familiar in the coming months and years: William James, Alfred Schutz, Aron Gurwitsch, Dorion Cairns, and, of course, Husserl.

Leaving Lester's office that day, I walked away with the feeling that I was working with a unique scholar. Not only did Lester seem more gifted than most the professors I had encountered up until that time, but he had what I felt was a historically-attuned perspective on things, an attitude and way of interacting with important philosophers of the past as a true peer among them. I sensed that his mind was consistently engaged in the philosophical conversation that 
extended beyond the present moment, as if the pantheon of philosophers whose gazes hovered above his desk continually reminded him of where is attention should be. It would suffice to say that I was impressed by Lester and came to respect him greatly, which for a long time persuaded me to behave in a strictly formal and professional manner with him. But as time would show, the more we worked together, the friendlier we became.

In his memoir, Out of Place, Edward Said remarked that his high level of productivity was due in part to the fact that he had little "concept of leisure", which is something I believe he and Lester had in common. Most days, Lester was up before dawn and out the door shortly after. On his way to the office, he would stop by the grocery to get breakfast, oftentimes a few hard-boiled eggs, a salad for lunch, and a quart of diet iced green tea, which he would usually finish by the end of the day, and then repeat the routine the next one. Arriving at the university, he parked in the same spot at the back end of the lot everyday so that, he explained to me once, he never had to think about where he parked; the extra walking it demanded he considered a key part of his daily exercise.

Once at the office, most mornings were spent reading and responding to emails, which he could produce with machine-like efficiency, some days writing several dozen. A portion of each morning was usually spent catching up on the news through his favorite outlets like the Huffington Post, the New York Times, the Daily Kos. Paul Krugman's popular blog, "The Conscience of a Liberal", was also essential daily reading. He was so devoted to reading Krugman that one time he once likened it to the closest thing to a religious devotion he'd had, but it was a devotion destined to not last forever. Over the 2015-2016 presidential election, Krugman came out as outspokenly pro-Hillary, which was almost anathema for Lester, who, many will remember, was a die-hard Bernie Sanders supporter. His devotion to Bernie's cause was extensive; he donated to the campaign, purchased buttons, printed and pasted pictures of Bernie around his office, and read about any developments in the primaries voraciously. It even provoked him to stop reading Krugman, the writer he had once so much admired. Even late in the electoral process, when Bernie's chances of gaining the nomination were slim-to-none, Lester championed the diminishing off-chance of him winning. As he was fond of saying, "hope springs eternal". 
When the nomination was cemented and Hillary's candidacy confirmed, Lester conceded begrudgingly with the diplomatic concession that he would "hold his nose" while casting his vote. On a Friday in October, as Lester was convalescing in a rehabilitation facility, I helped him fill out his absentee ballot and put it in the post for him. Despite the principled misgivings he had had, I remember the look of contentment on his face that day and the sense that we had accomplished something meaningful.

After a morning of emails and news, Lester would begin working on his seemingly endless list of research projects. His ability to hunker down with mulelike determination, spending hours at a time, day after day, diligently editing a manuscript or digging through Dorion Cairns's enormous Nachlass to chart the use of a particular term or phrase, was always impressive.

Around noon, Lester would have lunch at his desk, often returning to the news to catch any updates. These moments were often endlessly amusing to me because Lester gave himself the freedom to indulge in more sensational - even gossipy and salacious - news stories that float around places like The Huffington Post. He would read and chuckle at celebrity news, paparazzi photos, internet fads and lingo. Sometimes he would ask if a savvy Millennial like myself was privy to this or that new, zeitgeist-y trend (which I often was not). And while his incredulous reactions to these kinds of trivial articles were entertaining, I was also impressed that Lester, well into his 70s, had a kind of perennial with-it-ness that allowed him to engage with and appreciate, rather than feel alienated by, the wily twists and turns of contemporary culture, which was a tremendous credit to him.

Around 2 or 3 in the afternoon, Lester would head home to take his daily nap, or "siesta" as he liked to call it, but he always brought work home with him. After his rest, he would get back to work for several hours more. He was usually in bed at an early hour, but even that was not the end of his day. He had the odd habit of waking around midnight or 1 am to work for another hour or two at the desk nestled into the corner of his bedroom. Only after this would he go to bed for the final time to sleep for a few hours before waking up and beginning his routine again. 
Lester always felt that time was best spent researching and writing, which made him often view teaching as a kind of necessary evil to his profession. However, despite his apparent distaste for it, I saw him take pleasure in lecturing and interacting with students in the classroom, even though he rarely confessed as much. He enjoyed showing students how philosophy could clarify ideas, how relevant it was to everyday life-as much as he also he relished antagonizing conventional notions of things. Nevertheless, there was never any doubt that he felt his greatest duty was to produce research, and it was always his greatest satisfaction.

As such, summer months, holidays, and breaks in the semester were always only opportunities for catching up on research tasks. I became habituated to the eerie look of the vacant campus and desolate parking lots on those "days off" when the school was absent of virtually any warm bodies, the hallways becoming cavernous byways whose silence was only ever disturbed by him or me shuffling through it. I came to associate such solitude and stillness with unimpeded productivity. It occurred to me over the course of our working together that Lester spent most of his days in this kind of isolation, absent of people and sound, and wondered if there were moments he felt lonely as I might be tempted to in such a situation. But I never encountered any signs indicating so in all our hours together. By all appearances, he was totally contented by the busyness of his work, by the warmth of industry.

There were many times when, during one of our long, quiet workdays, I would break the silence to ask about some concept in our work I didn't quite grasp (while trying to suppress the feeling of being naïve for having to ask). Lester, without missing a beat, would often respond as if we had already been discussing the topic, launching into a clear, accessible answer and often going beyond what it demanded. He never balked at the simplicity of a query of mine or act as if his time was above dealing with such things; it simply seemed as though philosophy and phenomenology were always near the surface of his mind. Sometimes these questions would spark conversations about phenomenology or philosophy in general or politics that lasted as long as an hour in the middle of a workday, which were often the highlight of my day. They were always helpful and rich, and often brought philosophy to life for me in new ways. 
Lester's generosity in conversation was paralleled by a secret charitability with his possessions. He regularly marveled at how easy it was to make people feel special by giving them something, how simple it was to make someone's day. When he travelled, he made it a point to purchase gifts, usually little knickknacks but sometimes very fine things and sometimes half a dozen at a time, so that he could distribute them to friends, colleagues, even people he hardly knew at all when he got home. To this day, my wife has a drawer lined with very fine silk scarves given to her by Lester from his trips to Asia, Australia, Italy. When he was convalescing in the rehabilitation center after his injury, he asked me to withdraw from his bank account five $\$ 20$ bills for him to have so that he could surprise nurses whose services he particularly appreciated.

This was in concert with the fact that he regarded objects he owned with only a kind of tenuous ownership. Lester's home and office were filled with a truly idiosyncratic assortment of stone, steel, and wooden figurines that had been procured from all over the globe-little dragons, plump-bellied Buddhas, arrowheads, frogs, bears. It was not uncommon for office visitors unaccustomed to the kaleidoscope of objects to awe at one or all of them. There were several occasions when, upon hearing someone's passing appreciation for one of his things, he pulled the object down and gave it to them on the spot. The look of surprise and happiness that would emerge on the person's face was a moment Lester savored and something I think he never grew tired of.

After my first few visits to Lester's house, a painting of his caught my eye. It was a placid city street scene in muted blues and greens of children, a family on a walk, a bicyclist, a dog, in a simple, Henri Rousseau-like style. When he heard it was my wife's birthday the November before he passed, he told me to take it off the wall as a gift to her. I avoided taking the picture for some time, partly to make sure he was truly okay with parting with it, but he persisted in his request, and we enjoy the picture today.

Those close to Lester know that he endured a painful blow in 2013. After a perfunctory five-year-review, the university demoted him from his position as an eminent scholar, a position he had held since 1990 and had thought he would have for the duration of his career. It was a shock and a bitter loss for Lester that was made all the worse because Lester found the university's reasoning for 
the demotion dubious, which compelled him to develop an appeal against the decision. Many hours and sleepless nights were given to this task, but little progress was ultimately made in reversing it. Lester was forced out of his sprawling office for one a quarter of its size. He pared down books and furniture, moved most of his filing cabinets home, and did his best to maximize the new space. He filled three of his new office's walls with bookshelves, floor to ceiling, with the remaining wall for his desk. Within these walls of books, he squeezed a small fridge (on top of which he balanced the printer), and the pink dormitory couch from the old office. This became our little workspace. I worked on the couch behind him, using the arm of the couch as a prop for my laptop and the cushions a place for my papers and files. We developed a system and made the space surprisingly functional for our purposes, producing several volumes and articles while we were there.

After being in the new office for just a few months, Lester had made designs on the double-sized room at the end of the hall, hopes of converting it into his new sprawling office space dancing in his mind, but these hopes were dashed when a new secretary moved in there. Then his plans involved blowing out walls and merging one office with another, but these too were pipedreams. However, this was his habit: to never stop envisioning what could be.

In the summer of 2016, Lester set down a file box he was carrying in his house and heard a pop in his lower back. After having it examined a few weeks later, we learned that he had suffered two compression fractures, not an uncommon injury for someone his age. But we also learned that the medical procedure used to address such an injury was not a surefire fix: the procedure could fix the issue, but might also cause complications further down the road. The only other option was to wait for the injury to heal, which was the route taken by Lester. It was a difficult, uncomfortable route to take, the pain of which he managed with pills and pads and resting in bed for some weeks.

Lester endured a minor fall a few weeks thereafter and another one about a month after the first one, which sent him to a rehabilitation facility for a couple of weeks. This began the pattern of the last half of 2016-of entering rehabilitation, convalescing, going home, and then, finding things unmanageable, eventually returning to a facility. During this time, Lester constantly looked 
forward to the time when he would be physically revived. He continued to think about projects, had me compose and send emails for him, and even managed to do a little writing himself.

One day, while I was visiting him on a Friday to check in, he gave me a text he had scribbled on a yellow notepad, asking if I would type it into a word processor. He hoped it become a paper he would present when he got better. It is possibly the last thing Lester composed, and perhaps it is appropriate to include here. He entitled it "Notes on Being Disabled", and had planned on delivering at the PeacE conference in Tokyo that December:

Some months ago I fell and broke my back. After hospitalization and rehabilitation, I am home for further physical therapy. I can walk with a "walker" and take lots of pills. I should be practically normal in two more months or so.

These notes are phenomenological in the minimal signification: they are facts from my recent life. I begin with the social aspects and then report what ought be called the central aspects of my experience.

To begin with, there are medical people, doctors, nurses, and aids who come to the house to check blood pressure, heart beat, etc. Beyond that there could be traditionally family members who buy food, etc. In my case, I was lucky to have my son on leave from his job across the state for a month. He cleaned my house, bought lots of food, took my for doctor's appointments, etc. that I could not do myself. Since he has left, I have a "home health helper" two hours a day, seven days a week. She shops, cleans house, washes dishes, and takes care of laundry. These are things I like to be able to do without a thought, but now must carefully calculate for her to do.

Before I fell, I already had my "research assistant", whom I pay. He used to help with editing, proofing, etc., but now he also does my bills, checks my email correspondence, and takes me to doctor's appointments. These are still difficult if not impossible for me to do alone.

Most of the days, I just lay on my back and my situation is limited to what I can reach with my hands plus use of a "grabber" by which I can bring some things within reach. The most important things within reach are my pills, water, and diapers, plus the lights and heater. But much attention goes to my telephone (I can't word-process yet). Because my memory is still defective, I take lots of notes.

This is only the second paper I have tried to write. I hope it's useful for PeacE, which is the organization I am most proud of precipitating years ago in Delray Beach. My best to you all (and never break your back!).

As this short composition makes evident, Lester's hope for the future was as strong as ever when he wrote it. But by January another set of issues had arisen. Plans were put in place for them to be addressed, and though we all were hopeful of a turn-around, it seemed the months of struggle had taken its toll. I was at my home on a Thursday morning grading papers when I heard my cellphone 
chime, signaling the reception of a text message. It was a message from Lester's son saying that Lester had passed the night before.

During the span of months when Lester was resting at home, we began a routine of having lunch on Fridays at his home. We would pick up fast food and sit at his dining room table and talk. One day, I expressed how a book of his, George Gusdorf's Parole, had had a significant impact on me. I had discovered the gray, unassuming book when we were moving him from the big office to the small one. I was intrigued after briefly leafing through it and took it home to read. I was surprised to find in Gusdorf a kindred spirit whose thinking touched and inspired me. When I explained Gusdorf's effect on me to Lester, he was surprised because the book had left no such impression on him when he read it years before. So, without my prodding, he resolved to read it again so we could have a dialogue about it on our Friday lunches.

In the coming weeks, Lester reread the book chapter by chapter so that with each weekly visit he had some more reactions for me, and while we had interesting conversations about it, in the end, Lester's mind remained unchanged. The book appealed to him only intermittently, finding only the occasional passage insightful. (Gusdorf's very French, literary style did little for Lester, whose preference was always toward the concrete and pragmatic over the poetic.) But Lester's lack of enthusiasm for Gusdorf did not bother me. I was moved by his gesture to read the book at all, that he reread the book on my account solely to engage in a friendly intellectual exchange with me, which I found to be a real kindness.

On the wall behind where Lester sat during these talks hung a small ink sketch in a glass frame. It was of Lester's house, sketched in a loose, charming style by a friend who had stayed with him years before, and it conveyed the house's character well. His house was a Mediterranean style home built in the late 1940s. It had a long crescent driveway that wound beneath the canopy of several gnarled, old oak trees. An inviting front porch lined with rounded, pink columns and arches framed the front door. The sketch captured all of this, and had been titled, simply, "The Professor's House", a title that was always poignant to me. Calling his home "The Professor's House" evoked a kind of congenial affection for Lester on the artist's part, while also aligning Lester's humble home with the work of his life: being a Professor. In that home nestled in thickets of snake plant, palms, and oak he did so much of his thinking, his tireless working, 
his devising of projects. It was there that he ate and slept. And it was there that he made plans, looked forward to a future of possibilities, and, indeed, nurtured those hopes that, for Lester, sprang eternal. 